UDC 615.32

\title{
FATTY ACIDS COMPOSITION AND PHYSICO-CHEMICAL CONSTANTS OF PUNICA GRANATUM L. SEED OIL
}

\author{
(C) A.M. Zeynalova, E.N. Novruzov* \\ Botany Institute of the National Academy of Sciences of Azerbaijan, Badamdar \\ Highway 40, Baku, AZ1073 (Azerbaijan), e-mail: eldar_novruzov@yahoo.co.uk
}

One of the important sources of essential fatty acids may be products of plant origin, in particular, oils extracted from seeds of wild and cultivated plants. One of these resources is wild-growing Punica granatum. The fatty acid composition of the lipid fractions of the seeds of wild-type pomegranate growing on the territory of Galalti, Siyazan region of the Azerbaijan Republic was assessed by gas chromatography after conversion to the methyl esters of the corresponding fatty acids. The highest oil yield $-12.92 \%$ was obtained by the extraction of the seeds at $60^{\circ} \mathrm{C}$ for $8 \mathrm{~h}$ by Soxhlet extractor. Chromatographic analysis of the fatty oil of pomegranate seeds made it possible to establish the presence of 9 higher fatty acids. The main component of $P$. granatum seed oil was punicic acid (79.64\%). Palmitic and stearic acids were found in small quantities. Content of these fatty acids were $3.29 \%$ and $2.43 \%$, respectively. The least amount is accounted for by the share of myristic $(0.03 \%)$ and heptadecanoic acids $(0.03 \%)$. The analyses of physico-chemical constants and organoleptic properties of seed oil of $P$. granatum L. shows that the saponification numbers of wildtype pomegranate was 192.91 that indicates higher solubility of soap in water that can be made from it. The percentage of free fatty acids in our sample was $0.20 \%$ and the peroxide value -3.03 . The obtained results allow to consider the seed oil of this plant as good dietary fatty acid source. Thus, this study can provide valuable information for medicine and food industry for the development of drugs and food additives based on Azerbaijan wild-type pomegranate seed oil.

Keywords: pomegranate, fatty acids, gas-liquid chromatography, physico-chemical constants.

\section{Introduction}

Fatty acids, both free and as part of complex lipids, play a number of key roles in metabolism - major metabolic fuel (storage and transport of energy), as essential components of all membranes, and as gene regulators. As part of complex lipids, fatty acids are also important for thermal and electrical insulation, and for mechanical compression. Fatty acids are widely used as inactive ingredients in drug preparations, and the use of lipid formulations as the carriers for active substances [1]. Essential fatty acids cannot be synthesized in the body. These fatty acids must be supplied by foods. It is known that human need for essential fatty acids (arachidonic, linoleic, linolenic) is $2 \mathrm{~g} /$ day [2-4]. One of the important sources of essential fatty acids may be products of plant origin, in particular, oils extracted from seeds of wild and cultivated plants. Therefore, identifying new natural sources of essential fatty acids is a priority area for modern science. The use of essential fatty acids with antioxidant action prevents oxidative stress and slows down the aging process $[4,5]$. One of the sources of fatty acids is wild-growing P. granatum. Pomegranate is widely used as a traditional medicinal product in many parts of the world, such as America, Asia, Africa and Europe [6]. For medicinal purposes are used bark of trunks, branches and roots of pomegranate, seed oil, and also a fruit crust. The pomegranate seed oil has a cytotoxic and antitumor effect. It can be used for normalizes fat loss and lipid metabolism, strengthens the immune system, prevent and treat of several inflammatory diseases, such as inflammatory bowel disease, rheumatoid arthritis and coronary heart disease, reduces the accumulation of hepatic triglycerides and promotes the regeneration of epidermal tissue [7-9]. The above useful properties of the oil

Zeynalova Aydan Mirza gyzy - Junior Researcher,
e-mail: eldar_novruzov@yahoo.co.uk
Novruzov El'dar Novruz ogly - Doctor of Biological
Sciences, Associate Professor, Deputy Director for Research,
Head of Plant Resources Department,
e-mail: eldar_novruzov@yahoo.co.uk

e-mail: eldar_novruzov@yahoo.co.uk are associated with the content of a number of biologically active components in its composition, such as sterols, punicic acid and etc. In addition to fatty acids and lipids, seed oil also contains steroids, sterols, lignins, hydroxyl acids, phytosterols such as $\beta$-sitosterol, campesterol, stigmasterol and $\alpha-, \beta-, \gamma-, \delta$-tocopherols

\footnotetext{
${ }^{*}$ Corresponding author.
} 
[10-12]. In many studies were detected anti-inflammatory, immunomodulating, anti-cancer, anti-estrogenic effects of punicic acid [13-15].

Despite the large spectrum of biological activity of pomegranate seeds, plant seeds are still considered to be waste when processing fruits in the food industry and do not find wide application in the food industry and medicine. It has not been studied precisely the seed oil composition of wild-type pomegranate growing on the territory of Azerbaijan Republic. Therefore, the aim of this work was quantitative and qualitative determination of fatty acids in the seed oil of Azerbaijanian wild-growing pomegranate, as well as investigation of physico-chemical constants and organoleptic properties to explore their possible use in medicine and food industries.

\section{The experimental part}

Plant material. Plant material was collected in the month of Sept. 2018 from Siyazan region of Azerbaijan Republic. P. granatum L. seeds were obtained by manually removing of the pericarp from the rest of the fruit, isolating the endocarp and cleansing the tegumental pulp surrounding the seeds. Then, the seeds were washed in water and dried in the oven at $105^{\circ} \mathrm{C}$.

Extraction. The dried seeds $(273 \mathrm{~g})$ were crushed and ground with a grinding mill. The oil extraction of the seeds was carried out at $60^{\circ} \mathrm{C}$ for $8 \mathrm{~h}$ by Soxhlet extractor using $\mathrm{n}$-hexane as a solvent. The extract was evaporated by rotary evaporator and stored in a desiccator. The oil content was determined as a percentage of the extracted oil to the sample weight. The fatty acid composition was determined according to the GOST 31663-2012. The obtained oil was esterified to determine fatty acid composition.

Equipment. The fatty acid methyl esters were analyzed on chromatograph "HP" series 6890, equipped with a flame ionization detector. The separation was carried out on a capillary column "Agilent 112-88A7" (100 m, 0.25 $\mathrm{mm}$ i.d., $0.2 \mu \mathrm{m}$ ). The temperature program was: $140^{\circ} \mathrm{C}-5 \mathrm{~min}, 15 \mathrm{~min}$ - isotherm at $240{ }^{\circ} \mathrm{C}$, carrier gas-hydrogen, sample injection with flow division. The duration of the analysis was 45 minutes. Identification of fatty acids were carried out by comparing fatty acid methyl esters peak retention times with those obtained for Alltech standards.

\section{Results and discussion}

Chromatographic analysis of the fatty oil of pomegranate seeds made it possible to establish the presence of 9 higher fatty acids (Fig.). Oil yield was $12.92 \%$. According to literary data pomegranate seed oil represents between $12 \%$ and $20 \%$ of the seed total weight and consists chiefly of conjugated octadecatrienoic fatty acid - punicic acid [10].

The quantitative content and qualitative composition of fatty acids is presented in Table 1.

The data of the table show that the dominant fatty acids of the seeds were punicic $(79.64 \%)$, oleic $(6.53 \%)$ and linoleic $(6.27 \%)$ acids. Palmitic and stearic acids were found in small quantities. Content of these fatty acids were $3.29 \%$ and $2.43 \%$, respectively. The least amount is accounted for by the share of myristic $(0.03 \%)$ and heptadecanoic acids $(0.03 \%)$. According to literature data, the amount of punicic acid varies from 70 to $76 \%$ depending on the site of plant growth, also temperature, soil content, and altitude [16]. El-Shaarawy and Nahapetian report that $8 \%$ of fatty acids of pomegranate seeds are saturated, $10 \%$ are monounsaturated, $10 \%$ diunsaturated and approximately $70 \%$ would probably be punicic acid [17]. El-Nemr et al. report that $83.6 \%$ of the fatty acids of the pomegranate are saturated, $16.3 \%$ are unsaturated, Melgarejo point out that $30-35 \%$ of the fatty acids present in the pomegranate are saturated, $25-37 \%$ monounsaturates, $25-39 \%$ di-unsaturates, $1-10 \%$ polyunsaturates and approximately $67.6 \%$ would correspond to punicic acid $[18,19]$.

Punicic acid which is the dominant acid in pomegranate seed oil (79.64\%) according to the results of numerous studies showed biological activity in the prevention of the hazards associated with oxidative mechanisms. Punicic acid also has anti-inflammatory effect and can prove as a natural therapeutic agent against various inflammatory diseases [20]. Considering the fact that the essential fatty acid C18:2 enters the human body solely with food, its presence in the fatty oil of pomegranate is also a very positive fact.

Oxidative stability is an important indicator to determine oil quality and shelf life [21]. The level of unsaturation of the oils may be expressed by the iodine numbers. The peroxide value of oil is important property for the measurement of extent to which rancidity is produced due to autoxidation [22]. For this reason we also conducted a study of the physico-chemical constants and organoleptic properties of $P$. granatum L. seed oil. The results of these data are shown in Table 2. 


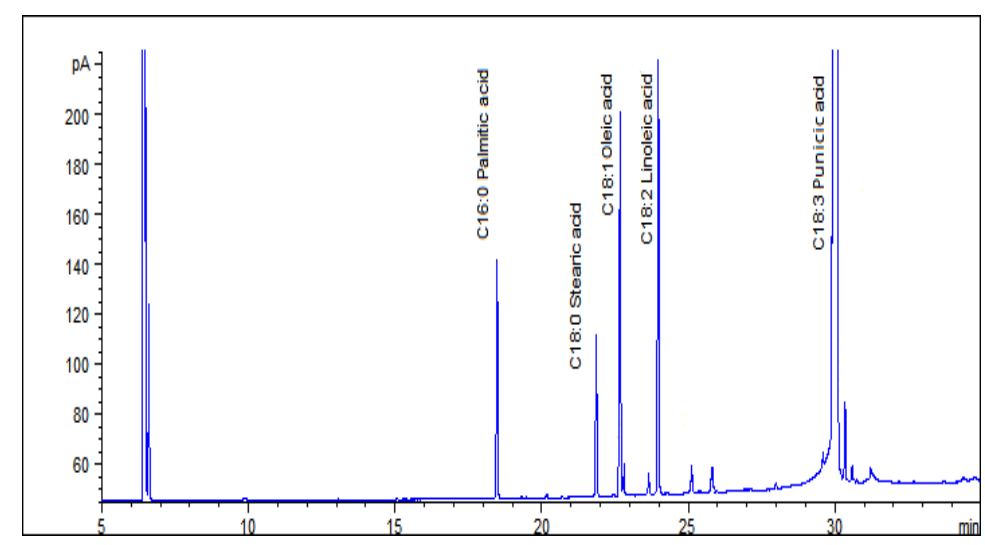

Gas-liquid chromatogram of fatty acid methyl esters in a sample of P. granatum L. seed oil

Table 1. Fatty acid composition of P. granatum L. seed oil

\begin{tabular}{l|c|c}
\hline \multicolumn{1}{c|}{ Fatty acid } & Content (\%) & Retention time, min \\
\hline C14:0 & 0.03 & 0.05 \\
C16:0 & 3.29 & 7.28 \\
C16:1 & 0.05 & 0.13 \\
C17:0 & 0.03 & 0.06 \\
C18:0 & 2.43 & 3.12 \\
C18:1 & 6.53 & 0.06 \\
C18:2 & 6.27 & 0.07 \\
C18:3 (9c11t13c) & 79.64 & 0.62 \\
C20:1 & 0.63 & 0.31 \\
Unsaturated fatty acid & 92.49 & - \\
Saturated fatty acid & 6.41 & - \\
\hline
\end{tabular}

Table 2. Physico-chemical constants and organoleptic properties of P.granatum L.

\begin{tabular}{l|c|c}
\hline \multicolumn{1}{c|}{ Experiment } & Test method & Result \\
\hline $\begin{array}{l}\text { Organoleptic parameters } \\
\text { appearance }\end{array}$ & GOST 5472-50 & $\begin{array}{c}\text { clear liquid } \\
\text { yellow } \\
\text { without smell } \\
\text { colour }\end{array}$ \\
smell & & inherent of seeds \\
taste & GOST R 50457-92 & 0.20 \\
Free fatty acids,\% & GOST 5477-2015 & 1.6 red, 6 yellow \\
Colour (Lovibond, $1 / 4 \mathrm{inc})$ & GOST R 51487-99 & 3.03 \\
Peroxide value, mmol $\mathrm{O}_{2} / \mathrm{kg}$ & GOST 5475-69 & 225.92 \\
Iodine value, IV & GOST 5478-2014 & 192.91 \\
Saponification value, $\mathrm{KOH}$ & GOST R 52676-2006 & 0 \\
Mass fraction of phosphorus-containing substances, $\mathrm{mg} / \mathrm{kg}$ & & \\
\hline
\end{tabular}

The saponification numbers in our case was 192.91 that indicates higher solubility of soap in water that can be made from it. The percentage of free fatty acids, which attributed due to the hydrolysis of oil, in our sample was $0.20 \%$. The peroxide value -3.03 , which means that the oil has a low rancidity.

\section{Conclusion}

The present study demonstrated that oil obtained from wild-growing pomegranate seeds contains in its composition 9 higher fatty acids. $6.41 \%$ of fatty acids of seeds are saturated, $92.49 \%$ are unsaturated. Among the isomers of octadecatrienic acids, only punicic acid (79.64\%) was detected in our sample, no other isomers were detected that is most likely due to the genotype of the fruit, harvest time and climatic conditions of the growing area. This research also reports physico-chemical constants and organoleptic properties of wild-type pomegranate oil. The obtained results allow to consider the seed oil of this plant as good dietary fatty acid source. Thus, this study can provide 
valuable information for medicine and food industry for the development of drugs and food additives based on Azerbaijan wild-type pomegranate seed oil.

\section{References}

1. Rustan A.C., Drevon C.A. Encyclopedia of life sciences, John Wiley \& Sons, 2005, pp. 1-7. DOI: 10.1038 /npg.els.0003894.

2. Schagen S.K., Zampeli V.A., Markantonaki E., Zoubolis C.C. Dematoendocrinol, 2012, vol. 4, no. 3, pp. 298-307. DOI: $10.14258 /$ jcprm.2018022005.

3. Boligitsin K.G., Kaplitsin P.A., Dobrodeyeva L.K., Drujinina A.S., Ovcinnikov D.V., Parshina A.E., Shulgina E.V. Sverkhkriticheskiye flyuidy: teoriya i praktika, 2016, vol. 11, no. 3, pp. 58-70 (in Russ.).

4. Velikorodov A.V., Kovalev V.B. Nosachev S.B., Tyrkov A.G., Morozova L.V. Khimiya rastitel'nogo syr'ya, 2018, no. 2, pp.153-158 (in Russ.).

5. St. Angelo A.J. Crit. Rev. Food Sci., 1996, vol. 36, no. 3, pp. 175-224.

6. Farag R.S., Abdel-Latif M.S., Emam S., Tawfeek S. Agriculture and Soil Sciences, 2014, vol. 1 (6), pp. 86-93.

7. Koba K., Imamura J., Akashoshi A., Kohno-Murase J., Nishizono S., Iwabuchi M., Tanaka K., Sugano M. Journal of agricultural and food chemistry, 2007, Vol. 55, pp. 3741-3748. DOI: 10.1021/jf063264z.

8. Sassano G., Sanderson P., Franx J., Groot P., van Straalen J., Bassaganya-Riera. Journal of the Science of Food and Agriculture, 2009, vol. 89, pp. 1046-1052. DOI: 10.1002/jsfa. 3552.

9. Caligiani A., Bonzanini F., Palla G., Cirlini M., Bruni R. Plant foods for human nutrition, 2010, vol. 65, pp. 277-283.

10. de Melo I.L.P., de Carvalho E.B.T., Mancini-Filho J. Journal of Human Nutrition \& Food Science, 2014, vol. 2 (1), 1024.

11. Boroushaki T.M., Mollazadeh H., Afshari A.R. IJPSR, 2016, vol. 7(2), pp. 430-442. DOI: 10.13040/IJPSR.0975$8232.7(2)$.

12. Amri Z., Lazreg-Aref H., Mekni M., El-Gharbi S., Dabbaghi O., Mechri B., Hammami M. Biomed. Res., 2017, pp. 1-8

13. Morikawa K., Nonaka M., Narahara M., Torii I., Kawaguchi K., Yoshikawa T., Kumazawa Y., Morikawa S. Life Sciences, 2003, vol. 74, pp. 709-721.

14. Yamasaki M., Kitagawa T., Koyanagi N., Chujo H., Maeda H., Kohno-Murase J., Imamura J., Tachibana H., Yamada K. Nutrition, 2006, no. 22, pp. 54-59. DOI: 10.1016/j.nut.2005.03.009.

15. Lansky E.P., Newman R.A. Journal of ethnopharmacology, 2007, vol. 109, pp. 177-206. DOI: 10.1016/j.jep.2006.09.006.

16. Monica V., Raquel H., Pinyi L., Josep B.R. Evidence-Based Complementary and Alternative Medicine, 2013, p. 18. DOI: $10.1155 / 2013 / 789764$.

17. El-Shaarawy M.I., Nahapetian A. European Journal of Lipid Science and Technology, 1983, vol. 85 (3), pp. 123-126. DOI: 10.1002/lipi.19830850307

18. El-Nemr S.E., Ismail I.A., Ragalo M. Die Nahrung, 1990, no. 34, pp. 601-606. DOI: 10.1002/food.19900340706.

19. Melgarejo P., Salazar, D.M., Amoros, A. J. Sci. Food Agr., 1995, vol. 69, pp. 253-256.

20. Aruna P., Venkataramanamma D., Singh A.K., Singh R. Compr. Rev. Food Sci. Food Saf., 2016, no. 15, pp. 16-27. DOI: $10.1111 / 1541-4337.12171$.

21. Marina A.M., Wan Rosli W.I., Noorhidayah M. The Open Conference Proceedings Journal, 2013, vol. 4, pp. 53-56. DOI: $10.2174 / 2210289201304020053$.

22. Mukasa-Tebandeke I.-Z., Ssebuwufu P.J.M., Nyanzi S.A., Schumann A., Nyakairu G.W., Lugolobi F. American Journal of Analytical Chemistry, 2014, no. 5, pp. 1302-1312. DOI: 10.4236/ajac.2014.517136.

Received February 13, 2019

Revised February 21, 2019

Accepted April 8, 2019

For citing: Zeynalova A.M., Novruzov E.N. Khimiya Rastitel'nogo Syr'ya, 2019, no. 4, pp. 259-262. (in Russ.). DOI: 10.14258/jcprm.2019045170. 